\title{
EVALUATION OF ACADEMIC MOTIVATION, A CASE STUDY OF ENG- LISH DEPARTMENT STUDENTS AT DUHOK UNIVERSITY.
}

\author{
Mohamad Salih A. Sulaiman and Shilan Majeed Mousa \\ Dept. of English, College of Languages, University of Duhok, Kurdistan Region-Iraq
}

(Received: May 27, 2019; Accepted for Publication: July 18, 2019)

\begin{abstract}
There is a vast body of literature that acknowledges an important relationship between motivation and academic performance. It confirms that motivation is crucial for learning, and it enhances academic performance among university students. This study reports the results of a survey exploring the students' perceptions on the teaching practices in a two-semester course of English Syntax, considering the components of the MUSIC model of academic motivation elaborated by Jones (2009). For this purpose, we used the MUSIC inventory (College Student version) developed by Jones (2012) to measure constructs related to the five components of the MUSIC model (i.e., eMpowerment, Usefulness, Success, Interest, and Caring) that are critical to students' motivation. That inventory has been shown to produce valid scores with samples of undergraduate students (Jones \& Skaggs, 2016; Tendhar, 2015). The inventory was administered to $904^{\text {th- }}$ year undergraduate students in the Department of English, College of Languages, University of Duhok, near the end of the second semester. They responded to the scale items in the MUSIC inventory by choosing one of six options on a Likert-format scale. The students' ratings of the components and aspects of the course that influenced their perception on it are discussed. Also, researchers' suggestions for improving the instructional design of the course from the perspective of the MUSIC motivational model are presented.
\end{abstract}

KEYWORDS: Motivation; MUSIC Model; Empowerment; Usefulness; Success; Interest; Caring

\section{INTRODUCTION}

A considerable amount of research has been done to explore the key factors that affect learning a second language. Among these factors are students' learning strategies, motivation, attitude, and learning environment. Motivation has been broadly recognized by scholars, researchers, and teachers as one of the major variables that determine the level and success of second language learning. Teachers' skills in motivating learners has been recognized as central to teaching effectiveness. Motivated learners are enthusiastic, eager to work hard, concentrate on the tasks given, do not require constant encouragement, willingly confront challenges, and could even motivate others (Jones,2009).

Such issues have not been explored extensively at University of Duhok,even though English is used as the medium of teaching and learning in most its colleges. The low performance of students in English departments at University of Duhok, has been a frequent and major topic of concern. Students who graduate from these de- partments have, apart from individual differences, weak levels of English language proficiency, especially in oral communication, even after 10 years of studying English formally in school and four years of extensive learning in the Department of English at the university. This research paper is an attempt to help instructors at the department of English of the college of languages at the University of Duhok to carry out research on students' perception on the presence of motivation components in the teaching strategies followed by instructors to identify areas of strength and weakness related to factors that affect students' motivation and engagement, and to provide recommendations for designing instruction that motivates students.

\section{Theoretical Background}

This section is a systematic presentation of the topic of motivation, its definition and the main theories of motivation, with focus on the MUSIC Model of academic motivation as developed by Brett Jones (2009), which will be presented and explained in detail. 


\subsection{Definitions of Motivation}

The term "motivation" comes from the Latin word "Movere" which means "to move". A motive is something that moves an organization to act (Agha, n.d., p.1). The Longman dictionary (1985, p.185) of applied linguistics defines motivation as:

"the factors that determine the person's desire to do something". In second and foreign language learning, learning may be affected differently by different types of motivation. Two types of motivation are sometimes distinguished:

a. Instrumental motivation: wanting to learn a language because it will be useful for certain "instrumental" goals, such as getting a job, reading a foreign newspaper, passing an examination.

$b$. Integrative motivation: wanting to learn a language in order to communicate with people or another culture who speak it (Procter,1985.p.185).

A more precise and complete definition of motivation is given by Richards and Schmidt (2002 p.p.343-344) stating that motivation is "the driving force in any situation that leads to action". Also Gredler, Broussard and Garrison (2004,p.106) define motivation as "the attribute that moves us to do or not to do something".

\subsection{Academic Motivation}

Academic motivation is a psychological process, which involves the appearance and evolvement of learning activities(Jones, 2009). Generally speaking, academic motivation refers to a students' desire regarding academic subjects when competence is judged against a standard of performance or excellence. Jones (2009,p. 272) defines academic motivation as "a process that is inferred from actions and verbalizations, whereby goal-directed physical or mental activity is instigated and sustained".

In the literature on academic motivation, there is distinction between intrinsic motivation and extrinsic motivation:

1. Intrinsic motivation is motivation that is caused by personal enjoyment, interest, or pleasure (Lai, 2011, p.4). Deci, Koestner \& Ryan (1999, p. 658) point out that intrinsic motivation stimulates and sustains activity through the spontaneous satisfaction of effective volitional action. It is evident in behaviors like play, exploration and challenge; in which people often seek external rewards (Lai, 2011,p.2). Intrinsic motivation implies that learning itself has its own recompense. It means that learners voluntarily attempt to learn what they think it is worth or important for them (Arnold, 2000, p. 14).

2. Extrinsic motivation is motivation controlled by reinforcement contingencies. Educators traditionally believe that intrinsic motivation is more desirable and leads to better learning outcomes than extrinsic motivation (Deci et al., 1999). Arnold (2000 p. 14) defines extrinsic motivation as a desire to gain a reward to shun punishment. He emphasizes the external need to encourage the learner to participate in learning activity, such as grade, homework or doing something to please teachers.

Motivation comes as a result of the gathering of closely related interests, beliefs, perceptions, values, and actions. As a result, different motivational approaches focus on cognitive behavior (such as monitoring and use of strategies), and non - cognitive aspects (such as beliefs, attitudes and perceptions).

\subsection{The MUSIC Model of Academic Motiva- tion}

The MUSIC model of academic motivation has been developed by Jones (2009). This model consists of five key components that instructors need to take into consideration when designing their courses. These components are: eMpowerment, Usefulness, Success, Interest, and Caing.

1. eMpowerment indicates to "the amount of perceived control that students have over their learning" (Jones,2009, p.272). It is students' perception that they do have control over their learning. This component is, to a large extent, related to the autonomy element of selfdetermination theory by Deci and Ryan's (2000). It is a common belief among researchers in the field of motivation that Learners enjoy activities and tasks when they have control over how to achieve them (ibid, p.274). Students are selfdetermined when they feel that they have a high level of freedom during activities, i.e., they are intrinsically motivated.

2. Usefulness refers to students need to understand the usefulness of the content they are studying. Many theorists have asserted that students' motivation is affected by their perceptions of the usefulness of what they are learning for their future (De Volder \& Lens, 1982; Kauffman \& Husman, 2004; Tabachnick, Miller, \& Relyea, 2008). Therefore, Instructors needs to ensure that students understand how the content is relevant to their future career. If the students 
understand how the material, they are learning can help them in achieving their goals, motivation will increase.

3. Success indicates that "humans have a need to be good at what they do" (Jones, 2009: p. 276). The students will be more motivated to engage in an activity, if they believe that they will be successful. Instructors need to provide students with tasks or activities that are completely challenging, in which the difficulty level corresponds to the students' ability levels so that students can succeed at challenging activities. Expectations need to be clearer and more concise, and complex learning activities need to be divided into manageable parts. Students also need to receive regular feedback about their level of competence, in the form of specific encouraging suggestions that will encourage them to do more. 4. Interest in the MUSIC model is consistent with Hidi and Renninger's interest theory (2006). They assume that "the potential for interest is in the person but the content and the environment define the dir7ection of interest and contribute to its development" ( p. 112). In other words, both the content and the class activities should interest students, and teachers needs to help students to enjoy their learning experiences. The instructors need to design class activities and tasks in ways that foster students' interest in the content (Jones, 2009, pp. 272-285).

5. Caring involves creating an environment in which students feel that the teacher cares about their well-being and learning (Jones, 2009). Noddings (1992, p. ix) points out that students tend to be more active in their coursework and perform better academically when they have close relationships with their teachers and classmates. Deci and Ryan (2000) use the term relatedness to describe "the desire to feel connected to others - to love and care, and to be loved and cared for" (p. 231). They suggest that although motivation may not require relatedness, it plays a role in increasing intrinsic motivation and gives students a sense of security and belonging that will increase the likelihood of participating in an activity (p. 235). If students experience relatedness, they may feel more comfortable asking and answering questions and participating in active learning. (Jones, 2009).

\section{METHOD}

This section is devoted to the discussion of methodology in our research. The first section deals with the problem and the nature of that problem. The nature of the problem will be explained and in the section (3.2) we will state our hypothesis and then we will point out the objectives of the study.

\subsection{The problem}

The low performance of students in English departments in college of languages at University of Duhok has been a frequent and major topic of concern. After four years of studying English as a foreign language in the department, students are unable to develop a satisfying level of communicative competence in speaking and also in academic writing. We believe that this problem is partly related to the absence of components of motivation in teaching practices and curricula designing. The study is an attempt to identify areas of strength and weakness related to factors that affect students' motivation and engagement in a $4^{\text {th }}$ - year syntax course, and to provide recommendations for designing instruction that motivates students.

\subsection{Hypotheses}

It is hypothesized that:

1. Teaching practices in the course under question lack motivational strategies needed to enhance students' learning of English language because students have no role in the teaching setting.

2. Students do not feel interested in the content of the course due to its irrelevance to their career demands.

3. There is a lack of instructors' caring about students' well-being and learning.

\subsection{Objectives}

This research aims at

1. Measuring the extent to which students perceive the presence of each of the MUSIC model components of motivation in their Syntax course.

2. Identifying areas of strength and weaknesses related to factors that affect students' motivation and engagement, and accordingly.

3. Identifying teaching strategies that can be used to motivate students, and

4. Providing recommendations for designing course materials that can attract students' interest and motivate them. 


\subsection{Procedures}

In conducting our research, we have followed a number of procedures, which can be summarized in the following points:

1. Selecting study participants from $4^{\text {th- }}$ year undergraduates in the Department of English.

2. Collecting data by using The MUSIC Inventory questionnaire which consists of 26 items that are organized into five scales that include five Empowerment items, five Usefulness items, four Success items, six Interest items, and six Caring items (Jones, 2014). The items in the questionnaire refer to teaching strategies associated with motivation components. All items are rated on a 6-point Likert scale format ranging from strongly disagree to strongly agree.

3. Analyzing the data by using Excel sheet.

4. Discussing statistical data to provide descriptive statements of the results and the main findings relevant to our research problem.

5. Drawing conclusions from the findings.

\subsection{The Sample}

The sample of this study consists of 90 undergraduate students of 4th year from the Department of English in the college of languages at University of Duhok.

The students were surveyed during the last two weeks of the second course in 2018. The students completed a paper-based questionnaire during the actual meeting time of a class, and they were told that the items in the questionnaire refer to teaching strategies that were used by their teacher in their syntax course.

\subsection{The Instruments}

The MUSIC Model of Academic Motivation Inventory (MMAMI) was administrated to the students to collect data about students' perception of motivation components in the teaching of the selected course. The MMAMI consists of 26 items which are related to the motivation components: eMpowerment, Usefulness, Success, Interest and Caring. The items which are put in written in the form of statements refer to teaching strategies that motivate students in learning. They are organized into five scales that include five eMpowerment items, five Usefulness items, four Success items, six Interest items, and six Caring items (Jones, 2014). All items are rated on a 6-point Likert scale ranging from strongly disagree to strongly agree. See appendix (A) for the MUSIC Model Inventory.

The questionnaire was administrated in regular classrooms in the college. The students were informed orally that they were participating in the survey to assess the degree of the presence or absence of the motivation components in the teaching practices of their syntax teacher in the classroom. The students were asked about the last course they had taken. The inventory was administrated on papers. They were also informed that the survey is not an achievement test, and there are no right or wrong answers, and that their teachers would not get an insight into their answers. The inventory was given to students, and they answered each statement one by one using the likert scale.

\section{Data Analysis:}

The students rated the items for each motivation component in the (MMAMI) on a 6-point Likert-type scale. The data provided by students' ratings of the items were analyzed using the SPSS program. The data were analyzed by averaging the values for the items for each MUSIC component scale. The mean scores for each component as well as the overall score were compared to find out students' perceptions of the five components as related to the courses in question.

\subsection{Results}

The ratings shown graphically in Figure (1) below demonstrate how students rated each of the components of the MUSIC model for the $4^{\text {th- }}$ year Syntax course. The mean scores for each component of the model were based on the values from corresponding items in the scale.

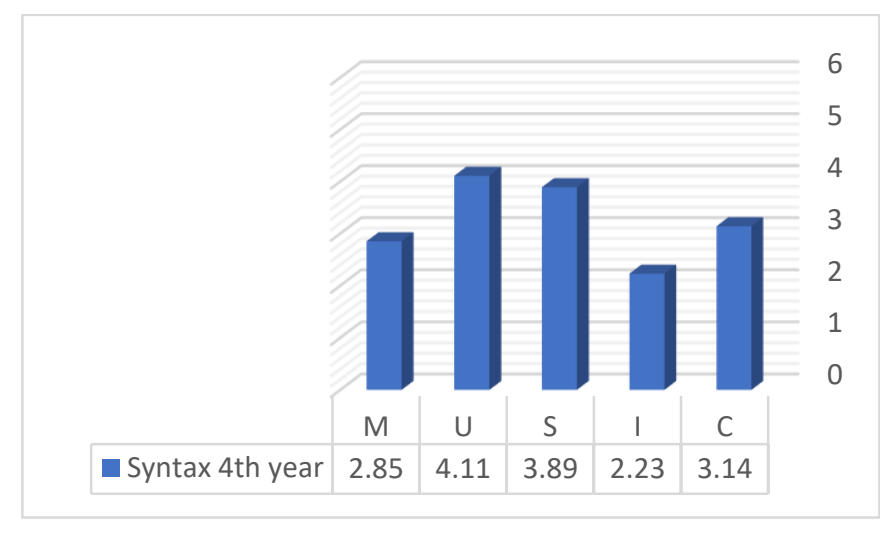

Figure 1: Assessment of motivation components for Syntax $4^{\text {th }}$ year course

Figure (1) shows that the students rated the items for both eMpowerment and Interest less than three $(2.85,2.23$ respectively), which re- 
flects their negative perceptions on both components. This means that the teacher needs to apply some more teaching practices to promote students' interest in the topic and also allows them to have some role in the teaching process. However, the ratings for Usefulness, Success and also Caring are somewhat high $(4.11,3.89,3.14$, respectively). These values indicate that students were somewhat satisfied with the course and support the idea that instructional practices implemented during the course did, to a certain extent, stimulate students' motivation for learning in terms of these three components. The results, however, diagnose that the teacher needs to optimize the instructional design of the course, and add more teaching practices to realize those components.

\subsection{DISCUSSION OF RESULTS}

Our discussion of the results in this section is based on students' ratings of the items in MMAMI. The mean scores for each component of the model are based on the values from corresponding items in the scale. In the following subsections, students' ratings for the items of each component of motivation will be discussed separately.

\subsection{1 eMpowerment}

Students' ratings for eMpowerment in $4^{\text {th }}$ year Syntax course were presented as shown in (table 1) below:

Table (1:) Ratings for Empowerment items (4 ${ }^{\text {th- }}$ year Syntax course)

\begin{tabular}{lll}
\hline Scales & Items by Scale & Ratings \\
\hline eMpowerment & & \\
& $\begin{array}{l}\text { 1. I had the opportunity to decide for myself how to } \\
\text { meet the course goals. }\end{array}$ \\
\hline $\begin{array}{l}\text { 2. I had the freedom to complete the coursework my } \\
\text { own way. }\end{array}$ & 3.10 \\
\hline $\begin{array}{l}\text { 3. I had options in how to achieve the goals of the } \\
\text { course. }\end{array}$ & 2.43 \\
\hline $\begin{array}{l}\text { 4. I had control over how I learned the course con- } \\
\text { tent. }\end{array}$ & $\begin{array}{l}\text { 5. I had flexibility in what I was allowed to do in this } \\
\text { course. }\end{array}$ \\
\hline
\end{tabular}

The Values Above Point Out That The Teacher Was Successful, To Some Extent, In Giving Students Some Freedom Concerning How To Meet The Course Goals And How To Complete The Coursework. However, The Teacher Needs To Add Teaching Practices That Encourage Students To Express Their Opinions,
And Provide Students With Choices As To The Materials They Can Use, The Strategies They Can Implement And The Topics They Can Study.

\subsubsection{Usefulness}

The students assigned high rates to the items that addressed the Usefulness component:

Table (2): Ratings for Usefulness items (Syntax $4^{\text {th }}$ - year).

\begin{tabular}{|c|c|c|}
\hline Scales & Items by Scale & Ratings \\
\hline \multicolumn{3}{|c|}{ Usefulness } \\
\hline & In general, the coursework was useful to me. & 4.10 \\
\hline & The coursework was beneficial to me. & 3.83 \\
\hline & I found the coursework to be relevant to my future. & 4.56 \\
\hline & I will be able to use the knowledge I gained in this course. & 3.96 \\
\hline & $\begin{array}{l}\text { The knowledge I gained in this course is important fo } \\
\text { future. }\end{array}$ & 4.10 \\
\hline
\end{tabular}

The values demonstrate students' positive perception on that the course, and that the Syntax fourth year course was useful and beneficial to them, relevant to their future career, and they 
can use the knowledge they gain from the course in their future career. Most of the items were rated high which indicates that the teacher was successful in ensuring that students understand the usefulness of the material and why the con- tent is so useful to their interests or to their career goals.

\subsubsection{Success}

The students rated the items for Success as in (Table 3) below:

Table (3:) Ratings for Success items ( $4^{\text {th- }}$ year syntax course).

\begin{tabular}{lll}
\hline Scales & Items by Scale & Ratings \\
\hline Success & & \\
& 1.I was confident that I could succeed in the coursework. & 4.00 \\
\cline { 2 - 3 } & $\begin{array}{l}\text { 2. I felt that I could be successful in meeting the academic chal- } \\
\text { lenges in this course. }\end{array}$ & 3.40 \\
\hline & $\begin{array}{l}\text { 3. I was capable of getting a high grade in this course. } \\
\end{array}$ & \\
\hline & $\begin{array}{l}\text { 4. Throughout the course, I felt that I could be successful on the } \\
\text { coursework. }\end{array}$ & \\
\hline
\end{tabular}

The results show that students have positive perceptions about their ability to succeed in that course, and the teacher was kind of good at setting high and reasonable course expectations. However, the teacher needs to provide some more learning activities that challenge all stu- dents, and set a variety of assignments that allow students to demonstrate their knowledge in different ways.

\subsubsection{Interest}

The students assigned low ratings to the Interest

items:

Table (4): Ratings for Interest items:

\begin{tabular}{lll}
\hline Scales & \multicolumn{1}{c}{ Items by Scale } & Ratings \\
\hline Interest & \multicolumn{1}{c}{ The coursework held my attention. } \\
\cline { 2 - 3 } & $\begin{array}{l}\text { The instructional methods used in this course held my } \\
\text { attention. }\end{array}$ & 1.80 \\
\hline $\begin{array}{l}\text { 4. I enjoyed the instructional methods used in this } \\
\text { course. }\end{array}$ & 2.06 \\
\hline $\begin{array}{l}\text { 5. The instructional methods engaged me in the } \\
\text { course. }\end{array}$ & 2.36 \\
\hline 6. I enjoyed completing the coursework. & 2.36 \\
\hline 7. The coursework was interesting to me. & 2.36 \\
\hline
\end{tabular}

The ratings show that the teacher was unsuccessful in attracting students' enthusiasm and interest for some course activities and content. Shel he needs to provide instructional methods that engage students in the course, select and design activities and content that relate to students' background knowledge and interest by asking students questions regarding things they are interested in or curious about. The teacher needs to select course activities that engender emotions to trigger students' emotions and generate positive feelings about the content, and, thus, make them believe that the coursework (assignments, activities, readings) is useful for their long-term goals.

\subsubsection{Caring}


Finally, the ratings for the Caring component ceptions concerning the instructor's academic items also show that students have negative per-

$$
\text { Caring for them }
$$

Table (5): Ratings for Caring items ( $4^{\text {th }}$ year Syntax)

\begin{tabular}{|c|c|c|}
\hline Scales & Items by Scale & Ratings \\
\hline \multicolumn{3}{|l|}{ Caring } \\
\hline & $\begin{array}{l}\text { The instructor was available to answer my questions about the } \\
\text { coursework. }\end{array}$ & 2.60 \\
\hline & $\begin{array}{l}\text { The instructor was willing to assist me if I needed help in the } \\
\text { course. }\end{array}$ & 2.60 \\
\hline & The instructor cared about how well I did in this course. & 2.93 \\
\hline & The instructor was respectful of me. & 2.96 \\
\hline & & 3.73 \\
\hline & The instructor was friendly. & \\
\hline & & 4.00 \\
\hline & I believe that the instructor cared about my feelings. & \\
\hline
\end{tabular}

The ratings above demonstrate that the teacher was good in regard to personal caring about students' feelings. The teacher was fairly successful in being friendly with the students. However, some teaching practices must be added to show the teacher's academic caring, such as, showing his/her care about how well the students did in the course, devoting time and energy into helping students, listening to students' opinions and ideas, and showing more concern for students' success and failures.

\subsection{Summary of Findings}

The statistical values in Figure (1) and our discussion of the results in section (4.2) provide inferences and implications that can be summarized in the following points:

1 . The students' ratings of the items for eMpowerment show their positive perceptions regarding teaching practices related to that component. The mean score (2.85) indicates that the teacher was, to a certain extent, unsuccessful in creating a sense of learner's autonomy. $\mathrm{He} / \mathrm{she}$ needs to provide options to how students can meet the goals of the course, give them control over how to learn the course content and the freedom to complete the coursework their own way. The teacher also needs to add some teaching practices such as giving the opportunity for the majority of students to decide for themselves how to achieve the course goals, and to let them have control over how they can learn the course content. . For this purpose the teacher can give the students choices like allowing them to control the pace of the lesson, giving them multiple due dates for quizzes and presentations, and giving students freedom in choosing activities in the class, the way to carry out the activities in the class.

2. The students rated the motivation component of Usefulness higher than (4), which indicates that the teacher was successful in demonstrating the usefulness of the content of his subject, the usefulness of the teaching activities within the classroom and also the relevance of the content to students' future careers.

3 . As for the items related to the Success component, the relatively high mean score (3.89) indicates that the teacher was successful in making students believe that they can succeed if they put forth effort. He/ She can raise this belief through providing clear directions for all assignments and providing learning activities that challenge students by dividing longer or more complex learning activities into manageable parts that challenge but do not overwhelm students.

4. The mean score for the items related to the Interest component (2.23) indicates that students' perceptions concerning the Interest components of motivation were negative. This low value indicates that the instructor of $4^{\text {th }}$-year syntax course need to pay more attention to certain teaching practices that can optimize students' interest in the content and the teaching activities. 
This can be achieved through designing course activities and selecting content that relates to students' background interest and knowledge, varying presentation style by using PowerPoint and content which is challenging, motivating and important, providing information that is surprising or inconsistent with students' prior knowledge, and thus to confront them to a state of cognitive conflict between what they expect and what they experience, which will certainly motivate them to solve the conflict and, thus, learn. The instructor can also use more video instructional materials and more electronic resources that may foster students' interest in the coursework.

5. Finally, the mean score for students' ratings of the items for the Caring component was (3.14), which reveals their kind of positive perceptions on some practices related to that component. The ratings indicate that the instructor needs to show more personal Caring to students' lives. $\mathrm{He} /$ she need to allocate more time outside the class to discuss students' problems and show them that $\mathrm{He} / \mathrm{she}$ really cares for their wellbeing. The instructor can also ask students questions regarding things they are curious about, show concern for their success and failures, listen and value their ideas and opinions, devote energy and time into helping them, and have them work in groups to meet course objectives and get to know one another on a personal level.

\subsection{CONCLUSION}

From the findings of this study, the following conclusions are drawn:

1. Motivation is an inner power that reinforces students' desire to learn, increases their initiative and gives them direction, courage and persistence to pursue their objectives. The results and findings of our study also confirmed this belief which is common to the literature on the topic of motivation

2. The students who rated the items in the MMAMI actually expressed their need to a curriculum and teaching practices that incorporate all the components of motivation. The instructor should consider students' perceptions and suggestions in order to improve the course's quality and promote students' motivation for it.

3. Being relatively unsuccessful in creating a sense of learner's autonomy, the instructor needs to strengthen students' role in the learning pro- cess as the perceptions of almost half of the students were negative on the eMpowerment component of motivation. This result partly verifies our first hypothesis. The instructors need to give students more control over how to learn the course content through providing options to how students can achieve the goals of the course, and a move from teacher-centered lectures to student-centered lectures.

4. The data provided by students on the Interest component of motivation show negative perceptions on both the teaching practices and the teaching material (2.23). This finding supports our second hypothesis (see 3.2), and accordingly we suggest that the teacher should incorporate the teaching practices suggested in our findings above to promote students' interest in the content through designing course activities and selecting content that relates to students' background interest and knowledge.

5. Similarly, the findings from analysis of data on the Caring component partly proves our third hypothesis (see 3.2) as the mean score (3.14) indicates that some of the students have relatively negative perceptions regarding items realizing that component. The researchers suggest that the instructor concerned should show more personal Caring to students' lives. They should allocate more time to discuss students' problems and show them that they really care for their wellbeing.

6 . The ratings assigned by students to items realizing the Usefulness and Success components were encouraging and reflected their positive perceptions on the teaching practices implemented by the instructor.

\section{REFERENCES}

Agha M. (n. d.). Motivation and Learning: A Perspective Motivationand Learning. Retrieved from https://www.merriam webster.com/dictionary/motive.

Arnold, J. (2000). Affect In language learning. Cambridge: Cambridge University Press.

De Volder, M., \& Lens, W. (1982). Academic achievement and future time perspective as a cognitive-motivational concept. Journal of Personality and Social Psychology, 42(3), 566-571.

Deci, E. L., \& Ryan, R. M. (2000). The "what" and "why" of goal pursuits: Human needs and the self-determination of behavior. Psychological Inquiry, 11 (4), 227-268. 
Deci, E. L., Koestner, R., \& Ryan, R. M. (1999). A meta-analytic re view of experiments examining the effects of extrinsic rewards on intrinsic motivation. Psychological Bulletin, 125(6), 627-668.

Gredler, Broussard, S. C., \& Garrison, M. E. B. (2004). The relationship between classroom motivation and academic achievement in ele mentary school-aged children. Family and Consumer Sciences Research Journal, 33(2), 106-120.College of Education, Gainesville, FL, USA.

Hidi, S., \& Renninger, K. A. (2006). The four-phase model of interest development. Educational Psychologist, 41(2), 111-127.

Jones, B. D. (2009). Motivating students to engage in learning: The MUSIC model of academic motivation. International Journal of Teaching and Learning in Higher Education, 21(2), 272-285.

Jones, B. D., \& Skaggs, G. E. (2016). Measuring students' motivation:

Validity evidence for the MUSIC Model of Academic Motivation Inventory. International Journal for the Scholarship of Teaching and Learning, 10(1). Retrieved from

http://digitalcommons.georgiasouthern.edu/ijsotl/vol10/iss $1 / 7$.

Jones, B.D. (2014). Motivating students by design: Practical strategies for professors. Charleston, SC: Create Space.
Kauffman, D. F., \& Husman, J. (2004). Effects of time perspective on student motivation: Introduction to a special issue. Educational Psychology Review, 16(1), 1-

7. https://doi.org/10.1023/B:EDPR.000001234 2.37854.58.

Lai, E.R. (2011) Motivation: A Literature Review. Pearson Research

Report.

Noddings, N. (1992) The challenge to care in schools: an alternative approach to education, New York: Teachers College Press.

Procter, P. (1985). Longman dictionary of contemporary English. Har low England: Longman, p.185.

Richards, J. \& R. Schmidt. (2002): Longman dictionary of teaching and applied linguistics. London education Limited.

Tabachnick, S. E., Miller, R. B., \& Relyea, G. E. (2008). The relationships among students' future-oriented goals and subgoals, perceived task instrumentality, and task-oriented selfregulation strategies in an academic environment. Journal of Educational Psychology, 100(3), 629-642.

http://dx.doi.org/10.1037/0022-0663.100.3.629 .

Tendhar C. (2015). Effects of Motivational Beliefs and Instructional Practice on Students' Intention to Pursue Majors and Careers in Engineering. Virginia Tech. 


\begin{tabular}{|c|c|c|c|c|c|}
\hline \multicolumn{6}{|c|}{ Instructions } \\
\hline & & & & & \\
\hline $\begin{array}{l}1 \\
\text { Strongly } \\
\text { disagree }\end{array}$ & $\begin{array}{l}2 \\
\text { Disagree }\end{array}$ & $\begin{array}{l}3 \\
\text { Somewhat } \\
\text { disagree }\end{array}$ & $\begin{array}{l}4 \\
\text { Somewhat } \\
\text { agree }\end{array}$ & $\begin{array}{l}5 \\
\text { Agree }\end{array}$ & $\begin{array}{l}6 \\
\text { Strongly } \\
\text { agree }\end{array}$ \\
\hline
\end{tabular}

Note that the word "coursework" refers to anything that you did in the course, including assignments, activities, readings, etc.

1. The coursework held my attention.

2. I had the opportunity to decide for myself how to meet the course goals.

3. In general, the coursework was useful to me.

4. The instructor was available to answer my questions about the coursework.

5. The coursework was beneficial to me.

6. The instructional methods used in this course held my attention.

7. I was confident that I could succeed in the coursework

8. I had the freedom to complete the coursework my own way.

9. I enjoyed the instructional methods used in this course.

10. I felt that I could be successful in meeting the academic challenges in this course.

11. The instructional methods engaged me in the course.

12. I had options in how to achieve the goals of the course.

13. I enjoyed completing the coursework.

14. I was capable of getting a high grade in this course.

15. The coursework was interesting to me.

16. The instructor was willing to assist me if I needed help in the course.

17. I had control over how I learned the course content.

18. Throughout the course, I felt that I could be successful on the coursework.

19. I found the coursework to be relevant to my future.

20. The instructor cared about how well I did in this course.

21. I will be able to use the knowledge I gained in this course.

22. The instructor was respectful of me.

23. The knowledge I gained in this course is important for my future.

24. The instructor was friendly.

25. I believe that the instructor cared about my feelings.

26. I had flexibility in what I was allowed to do in this course.

"Thanks for your cooperation" 